\title{
OPTIMALISASI ANGGARAN KEUANGAN DI MASA PANDEMI PADA DESA CICALENGKA KABUPATEN PAGEDANGAN TANGERANG
}

\author{
Sri Mardiana, Wawan Supriyatna, Yenny Merinatul Hasanah, Zakaria, \\ Indri Indirasari \\ Universitas Pamulang \\ Email: dosen02065@unpam.ac.id
}

\begin{abstract}
The purpose of this community service is to provide counseling and socialization regarding the optimization of the financial budget during the pandemic in Cicalengka Village, Pagedangan Regency, Tangerang. The method used in this community service activity is the socialization stage, the observation stage, and the community service implementation stage to help village official apparatuses understand and use village funds in accordance with the community partnership program set by the central government. Most of the village apparatuses have not been able to manage budget funds according to plan because of limited knowledge and socialization regarding the function of this village fund budget. Village officials apparatuses, including the Village Head and his/her staffs, must be able to manage with certainty so that the benefits of this village fund can influence and develop the local community. With the distribution of village funds by the central government, it can also create new jobs for the community, such as opening tourist locations that require new workers in their management so with that they can empower the community, build new educational places for early childhood children (PAUD) or build places or buildings for playground for children. Village funds will be more effective if village official apparatuses can work together as a team in achieving the goals of an independent village.
\end{abstract}

Keywords: Optimization of Financial Budget, Village Officials.

\begin{abstract}
Abstrak
Tujuan dilakukannya pengabdian masyarakat ini adalah untuk memberikan penyuluhan dan sosialisasi mengenai optimalisasi anggaran keuangan di masa pandemi pada Desa Cicalengka Kabupaten Pagedangan Tangerang. Metode yang digunakan dalam kegiatan pengabdian masyarakat ini adalah dengan tahap sosialisasi, tahap observasi, dan tahap pelaksanaan. Pengabdian Kepada Masyarakat ini membantu perangkat desa dalam memahami dan menggunakan dana desa sesuai dengan program kemitraan masyarakat yang di tetapkan oleh pemerintah pusat. Perangkat desa sebagian besar belum mampu mengelola dana anggaran sesuai rencana di sebabkan oleh keterbatasan pengetahuan dan sosialisasi mengenai fungsi dari Anggaran dana desa ini. Perangkat desa termasuk Kepala Desa dan jajarannya harus mampu secara pasti dalam pengelolaan sehingga manfaat dana desa ini
\end{abstract}


dapat membangun masyarakat sekitar. Dengan adanya penyaluran Dana desa oleh pemerintah pusat juga dapat menciptakan lapangan kerja baru untuk masyarakat seperti pembukaan lokasi wisata yang membutuhkan tenaga kerja baru dalam pengelolaannya sehingga dapat memberdayakan masyarakat, membangun tempat pendidikan baru untuk anak usis dini (PAUD) atau membangun tempat atau gedung untuk taman bermain untuk anak-anak. Dana desa di rasa efektif jika perangkat desa bisa secara bahu membahu dalam bekerja demi mencapai tujuan desa yang mandiri.

Kata Kunci: Optimalisasi Anggaran Keuangan, Perangkat Desa.

\section{A. PENDAHULUAN}

Desa Cicalengka adalah salah satu desa yang berada di Kecamatan Pagedangan Kabupaten Tangerang, Provinsi Banten, Indonesia. Di kecamatan ini terletak perumahan besar yang bernama Gading Serpong atau kini disebut sebagai Summarecon Serpong, yang kini akan menjadi kota modern yang disebut dengan Summarecon Serpong dan BSD City, tepatnya di Desa Cihuni. Di kecamatan ini juga terdapat Perum Puspitek, yang masuk ke dalam wilayah Desa Pagedangan dengan Kepada Desa bernama Absor, S.Pd. I dan mulai menempati posisi Kepala Desa di 1 Desember 2019.

Latar belakang masalah dalam pengabdian kepada masyarakat ini antara lain berdasarkan observasi lapangan mengenai optimalisasi pengelolaan dana desa pada masa pandemi covid-19 karena Desa sebagai penyelengaraan pemerintah terkecil namun merupakan unit terdepan dalam pelayanan kepada masyarakat dan bagian yang strategis untuk keberhasilan semua program pembangunan. Karena itu, upaya untuk memperkuat desa (Pemerintah Desa dan Lembaga Kemasyarakatan) merupakan langkah mempercepat terwujudnya kesejahteraan masyarakat sebagai tujuan otonomi daerah.

Terkait dengan hal itu, dalam rangka perencanaan pembangunan desa dan guna mengurangi kesenjangan antara kota dan desa, pemerintah menerbitkan Undang-Undang Nomor 6 Tahun 2014 tentang Desa. UU Desa memberikan kewenangan lebih besar kepada pemerintah desa untuk melakukan perencanaan, penganggaran, dan pelaksanaan keuangan desa dalam rangka pembangunan di desa. Pasal 72 ayat (1) dan (2) UU Desa (Anonimous, 2014) menyebutkan bahwa salah satu sumber pendapatan desa berasal dari alokasi APBN dengan mengefektifkan program yang berbasis desa secara merata dan berkeadilan. Selanjutnya, penjelasan dari pasal tersebut menyatakan Dana Desa yang dialokasikan dari APBN adalah sebesar $10 \%$ dari dan di luar dana transfer ke daerah (on top) dan dilakukan secara bertahap.

Secara umum, permasalahan yang muncul berkaitan dengan pengelolaan keuangan desa adalah dalam proses perencanaannya masih bersifat parsial dan insidentil. Hanya dilakukan pada saat penyusunan Rencana Anggaran Pendapatan dan Belanja Desa (APBDes). Tujuan dari pengabdian ini untuk memberikan penyuluhan dan sosialisasi kepada kepala desa, sekretaris desa, BPD, dan masyarakat optimalisasi anggaran keuangan desa pada masa pandemi covid-19 di desa Cicalengka Kabupaten pegedangan Tangerang Banten.

Di harapkan dengan adanya penyuluhan dan sosialisasi ini dapat membantu perangkat desa dalam memahami dan menggunakan dana desa sesuai dengan program kemitraan masyarakat yang di tetapkan oleh pemerintah pusat. Perangkat desa sebagian besar belum mampu menerapkan sesuai rencana di sebabkan oleh keterbatasan pengetahuan dan sosialisasi menenai fungsi dari Anggaran dana desa ini. Perangkat desa termasuk Kepala 
Desa dan jajarannya harus mampu secara pasti dalam pengelolaan sehingga manfaat dana desa ini dapat membangun masyarakat sekitar. Dengan adanya penyaluran Dana desa oleh pemerintah pusat juga dapat menciptakan lapangan kerja baru untuk masyarakat seperti pembukaan lokasi wisata yang membutuhkan tenaga kerja baru dalam pengelolaannya sehingga dapat memberdayakan masyarakat, membangun tempat pendidikan baru untuk anak usis dini (PAUD) atau membangun tempat atau gedung untuk taman bermain untuk anakanak. Dana desa di rasa efektif jika perangkat desa bisa secara bahu membahu dalam bekerja demi mencapai tujuan desa yang mandiri.

\section{B. METODE PELAKSANAAN}

Tempat dan mitra Pengabdian Kepada Masyarakat (PKM) kali ini berlokasi di Kantor Desa Cicalengka Pagedangan Jalan Raya Pagedangan No. 68, Cicalengka Tangerang Banten. Adapun pelaksanaan kegiatan PKM dilaksanakan pada tanggal 5 -6 September 2020. Karena khalayak sasaran dari kegiatan pengabdian kepada masyarakat ini adalah perangkat desa Cicalengka Kabupaten Pagedangan Tangerang Banten. Penyuluhan ini didasarkan pada pengajaran dan sosialisasi tentang optimalisasi anggaran keuangan. Metode dalam pelaksanaan kegiatan pengabdian ini dilakukan dalam beberapa tahap, yaitu:

1. Tahap Observasi

Kegiatan ini dilaksanakan sebagai awal kegiatan dengan tujuan untuk memperoleh deskripsi kondisi komunitas yang dituju; yaitu dengan mengadakan pertemuan dengan Kepala Desa Cicalengka yaitu Bapak. Absor, S. Pd.I.

2. Tahap Sosialisasi

Dalam tahap ini, tim pengabdian akan memberikan dan menjelaskan rencana pengabdian yang akan dilakukan sehingga dapat diatur waktu dan berbagai keperluan teknis sehubungan dengan pelaksanaan pelatihan secara keseluruhan.

3. Tahap Pelaksanaan

Penyuluhan Pelaksanaan pengabdian kepada masyarakat ini dilakukan dengan kerjasama dari pihak perangkat desa Cicalengka Pagedangan. Dalam penyuluhan perangkat desa tersebut akan diberikan penjelasan tentang optimalisasi anggaran keuangan di masa pandemi.

\section{HASIL DAN PEMBAHASAN}

\section{Tahap Observasi}

Tahap observasi ini dilakukan sebanyak dua kali kunjungan. Kunjungan pertama dilakukan untuk menemui kepala desa Cicalengka untuk mengetahui keperluan perangkat desa dalam pemahaman terhadap budgetting dan untuk pelaksanaan alokasi dana desa. Pada kunjungan kedua, observasi dilakukan dengan wawancara secara informal kepada perangkat desa termasuk kepala desa untuk mengetahui secara jelas pemahaman mereka dan sekaligus mengadakan pemetaan dalam penentuan pemberian materi saat mengadakan Pengabdian Kepada Masyarakat. Pada umumnya mereka merasa perlu ilmu dan pengetahuan yang cukup tentang optimalisasi anggaran keuangan desa khususnya di masa pandemic ini. Pada kesempatan ini tim pengabdian masyarakat mendapatkan informasi mengenai tema apa saja yang dapat dipersiapkan untuk pelatihan nantinya.

\section{Tahap Sosialisasi}

Sosialisasi ini terlaksana pada bulan Agustus pertengahan. Tahap ini dilakukan sebanyak dua kali kunjungan. Pada kunjungan pertama, tim pengabdian masyarakat 
memberikan surat pengantar dan penjelasan kepala Desa Cicalengka, Bapak Absor S.Pd.I sehingga beliau nanti bisa menyampaikan maksud dan tujuan kegiatan ini kepada perangkat desa. Kunjungan kedua dilakukan sebagai upaya mengetahui konfirmasi dari pihak Desa yang diwakili oleh kepala desa Cicalengka BapakAbsor, S. Pd.I mengenai jadwal kegiatan, yang berkenaan dengan hari dan waktu pelaksanaan kegiatan, latar belakang para peserta, jumlah peserta, dan persiapan materi.

\section{Tahap Pelaksanaan Pengabdian}

Tahap ini dilaksanakan pada tanggal 5-6 September 2020, sebanyak dua kali pertemuan. Setiap pertemuannya berlangsung selama 2 jam. Di hari pertama Materi yang diberikan yaitu berjudul "Optimalisasi anggaran keuangan di masa pandemi. Materi yang diberikan untuk pelatihan dan penyuluhan yang di sampaikan oleh Bapak Zakaria, S. Sos., M.M. dan di lanjutkan dengan sesi pembelajaran pembuatan anggaran di pandu oleh Ibu Yenny Merinatul Hasanah, S. Pd. I., M. Pd Pada sesi ini di lanjutkan dengan sesi tanya jawab guna mengetahui sampai sejauh mana peserta memahami materi. Di hari berikutnya pemberian materi lanjutan di sampaikan oleh Bapak Wawan Supriyatna, S. Kom., M.M dan di lanjutkan dengan sesi Tanya jawab kembali di pandu oleh Ibu Indri Indirasari, S.E., M.M. Kegiatan di hari kedua ini pesertasudah mulai memahami materi terlihat dari penyampaian jawaban yang mereka kemukakan saat Tanya jawab.

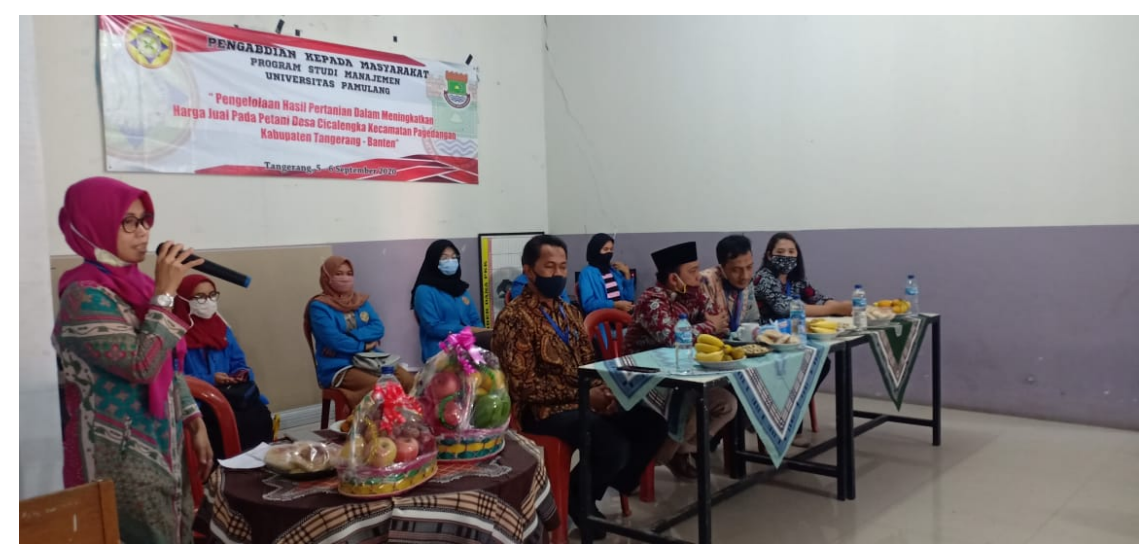

Gambar 1. Pemberian Materi Kepada Warga

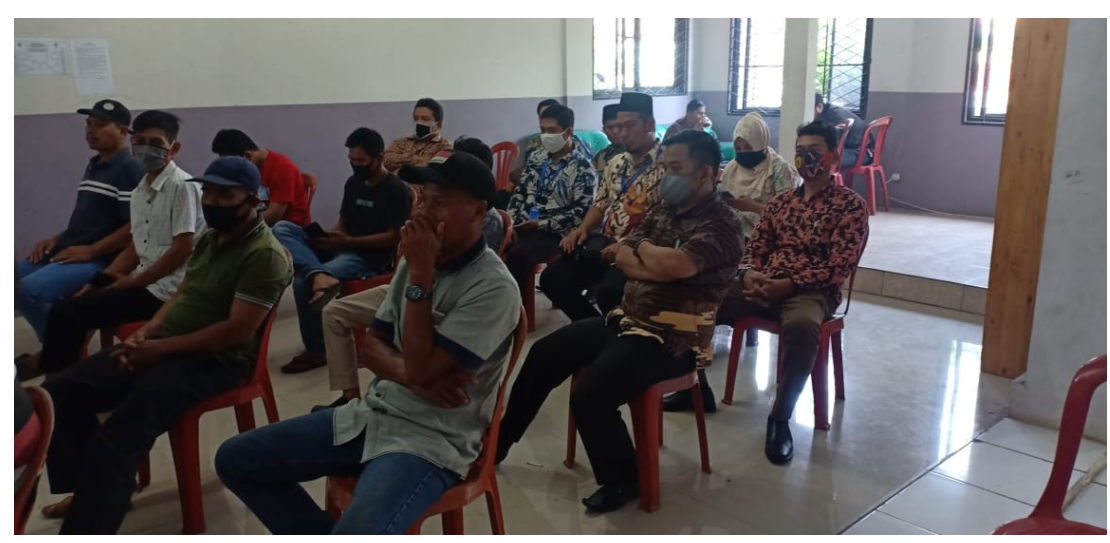

Gambar 2. Warga Antusias Mengikuti Kegiatan PKM 


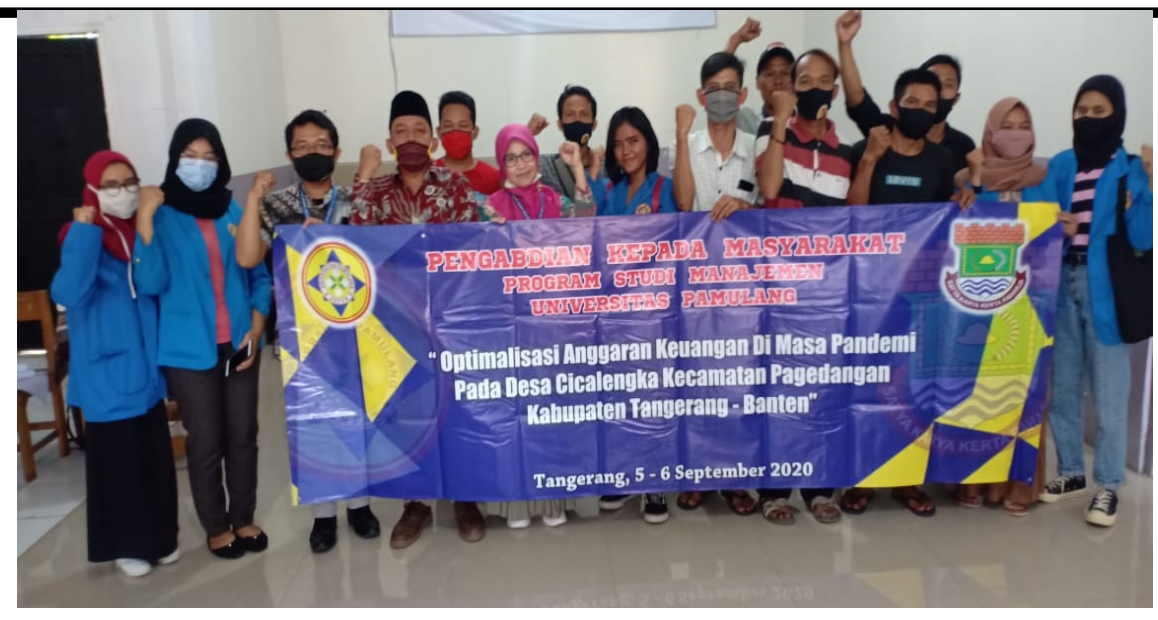

Gambar 3. Foto bersama Kepala Desa dan Warga

\section{KESIMPULAN DAN SARAN}

\section{Kesimpulan}

Pelaksanaan kegiatan Pengabdian Kepada Masyarakat oleh Lembaga Penelitian dan Pengabdian Masyarakat (LPPM) Universitas Pamulang yang dilakukan oleh dosen-dosen program studi Manajemen sudah berjalan dengan lancar. Dengan adanya pemberian materi sangat membantu peserta terutama para perangkat desa dalam belajara memahami materi optimalisasi anggaran khususnya di masa pandemi . Harapan kami dengan pengabdian ini dapat menambah ilmu yang bermanfaat dalam hal penggaran keuangan untuk para perangkat desa Cicalengka. Dalam laporan kegiatan ini masih banyak kekurangan, untuk itu kami berharap masukan dan kritikan dalam rangka perbaikan untuk kegiatan-kegiatan pengabdian masyarakat di masa yang akan datang. Semoga kegiatan pengabdian masyarakat ini dapat bermanfaat bagi masyarakat sekitar lingkungan Universitas Pamulang dan lainnya.

Akhirnya, kami mengucapkan terima kasih kepada seluruh pihak yang telah mendukung kegiatan Pengabdian Kepada Masyarakat ini.

\section{Saran}

Berdasarkan hasil kegiatan Pengabdian Kepada Masyarakat, maka kami dari Tim Dosen Universitas Pamulang memberikan saran diantaranya sebagai berikut:

1. Untuk para perangkat desa diharapkan rutin melakukan tahapan yang sudah di berikan saat pemaparan materi pelatihan Pengabdian Kepada Masyarakat berlangsung. Sehingga ilmu yang di dapatkan selalu berguna untuk masa pandemi ini dan masa mendatang.

2. Adanya kontribusi dari pihak universitas untuk bisa memberikan fasilitas dalam pelayanan kepada masyarakat dalam bentuk sarana dan prasarana.

\section{Ucapan Terima Kasih}

Rasa syukur dan suka cita kami sampaikan kepada segenap pihak yang telah mensukseskan kegiatan PKM dengan judul “ Optimalisasi Anggaran Keuangan Di Masa Pandemi pada Desa Cicalengka Kabupaten Pagedangan Tangerang Banten" yaitu:

1. Rektor Dr. H. Dayat Hidayat, M.M, Rektor Universitas Pamulang Tangerang Selatan Banten.

2. Dr. Ali Maddinsyah, S.E., M.M., selaku Ketua LPPM Universitas Pamulang Tangerang Selatan - Banten. 
3. Dr. Kasmad, S.E., M.,M., selaku Ketua Program Studi Manajemen Universitas Pamulang Tangerang Selatan - Banten.

4. Dr. Udin Ahidin, S.E., M.M., C.M.A, Selaku Wakil Program Studi Manajemen Universitas Pamulang Tangerang Selatan - Banten.

5. Drs. Waluyo Jati, M.M., Selaku Sekretaris Program Studi Manajemen Universitas Pamulang Tangerang Selatan - Banten.

6. Absor, S. Pd.I, selaku Kepala Desa Cicalengka Kabupaten Pagedangan Tangerang Banten

7. Mahasiswa Universitas Pamulang yang juga ikut berkontribusi terhadap kelancaran kegiatan PKM.

8. Perangkat Desa Cicalengka Kabupaten Pagedangan Tangerang Banten.

\section{DAFTAR PUSTAKA}

Anonimous. (2014). Undang-Undang Nomor 6 Tahun 2014 tentang Desa: Jakarta.

BPKP. (2015). Juklak Bimkon Pengelolaan Keuangan Desa. Jakarta: Deputi Bidang Pengawasan Penyelenggaraan Keuangan Daerah.

Mardiana, S., Supriyatna., W., Zakaria, Dumilah, R., \& Budhiarjo, I. S. (2020). Sosialisasi Dan Penyuluhan Tentang Pentingnya Menabung Bagi Generasi Muda Khususnya Siswa Madrasah Tsanawiyah Mts Mathlaul Anwar Pamulang. DEDIKASI PKM. Vol. 1. No. 2.

Kementrian Keuangan Republik Indonesia. (2017). Jakarta: Buku Pintar Dana Desa.

Yayuk, Y. Dan Mangku P. (2003). Sosiologi Pedesaan. Yogyakarta: Lapera Pustaka. 